\title{
Yoğun Bakım Hastalarında Müzik Uygulamasının Fizyolojik ve Psikolojik Etkileri: Sistematik Derleme
} $\infty$

\author{
Yasemin SAZAK $^{1}$, Keriman AYTEKIN KANADLI ${ }^{2}$, Nermin OLGUN ${ }^{3}$
}

\section{Öz}

Amaç: Bu sistematik derleme ile yoğun bakım hastalarında müzik uygulamasının hastalar üzerindeki fizyolojik ve psikolojik etkilerinin belirlenmesi amaçlanmıştır.

Gereç ve Yöntem: Konuyla ilgili 1 Ocak 2014-25 Eylül 2019 tarihleri arasında "intensive care units", "music therapy", "music", "critical care" MesH terimleri ve Türkçe olarak "yoğun bakım", "müzik terapi" ve "müzik" terimleri kullanılarak CINAHL, Pubmed, Medline, Ovid, Web of Science, Complementary Index, Science Direct, Academic Search Complete, Scopus, ULAKBiM Ulusal Veri Tabanları ve Google Akademik veri tabanlarında tarama yapılımıştır. Araştırma kapsamına 12 çalışma dahil edilmiştir.

Bulgular: Müzik uygulamasının; sistololik kan basıncı değerlendirilen çalışmaların \%85.7'sinde, diyastolik kan basıncı değerlendirilen çalışmaların \%57.1'inde, ortalama arter basıncı değerlendirilen çalışmaların \%33.3'ünde, nabız hızı değerlendirilen çalışmaların \%70'inde, solunum hızı değerlendirilen çalışmaların \%66.7'sinde, oksijen satürasyonu değerlendirilen çalışmaların $\% 55.5^{\prime}$ inde, anksiyete düzeyi değerlendirilen çalışmaların $\% 87.5$ 'inde, ağrı değerlendirilen çalışmaların \%85.7'sinde olumlu etkisinin olduğu saptanmıştır. Müziğin hastaların; konfor düzeyi, sedasyon düzeyi, dispne durumu, ventilasyondan ayırma süresi, subjektif uyku kalitesi, serum kortizon değerleri üzerinde de olumlu etkileri olduğu belirlenmiştir.

Sonuç: Müzik uygulamasının yoğun bakım hastalarııın yaşam bulgularına, anksiyete, sedasyon, ağrı, uyku kalitesi ve konfor düzeylerine olumlu etkileri olduğu belirlenmiştir.

Anahtar kelimeler: Bakım, hemşirelik, müzik, müzik terapi, yoğun bakım

\begin{abstract}
Physiological and Psychological Effects of Music Application on Intensive Care Patients: A Systematic Review
\end{abstract}

Aim: This systematic review aimed to determine the physiological and psychological effects of music application on intensive care patients.

Material and Methods: A literature search was conducted using the terms "intensive care units", "music therapy", "music", and "critical care" on CINAHL, Pubmed, Medline, Ovid, Web of Science, Complementary Index, Science Direct, Academic Search Complete, Scopus, ULAKBIM National Databases and Google Scholar databases in Turkish and English among studies which were carried out between January 1, 2014 and September 25, 2019. As a result of the search, 12 studies were included in the study.

Results: It was found that the application of music had a positive effect in $85.7 \%$ of studies evaluating systolic blood pressure, $57.1 \%$ of studies evaluating diastolic blood pressure, $33.3 \%$ of studies evaluating mean arterial pressure, $70 \%$ of studies evaluating pulse rate, $66.7 \%$ of studies evaluating respiratory rate, $55.5 \%$ of studies evaluating oxygen saturation, $87.5 \%$ of studies evaluating anxiety level, $85.7 \%$ of studies evaluating pain. Music has also been found to have positive effects on patients' comfort level, sedation level, dyspnea status, weaning time, subjective sleep quality, and serum cortisone levels.

Conclusion: It was determined that music application has positive effects on the vital signs, anxiety, sedation, pain, sleep quality, and comfort levels of intensive care patients.

Keywords: Care, intensive care units, music, music therapy, nursing

${ }^{1}$ Öğr. Gör., Kahramanmaraş İstiklal Üniversitesi Elbistan Sağlık Hizmetleri Meslek Yüksekokulu, Kahramanmaraş, Türkiye, E-posta: yaseminsazak44@gmail.com, Tel: 0541 44749 44, ORCID: 0000-0001-9296-0719

${ }^{2}$ Öğr. Gör., Mustafa Kemal Üniversitesi Sağlık Uygulama ve Araştırma Hastanesi Uygulamalı Birim, Hatay, Türkiye, E-posta: keriman.akanadli@gmail.com, Tel: 0506443 42 38, ORCID: 0000-0003-3468-241X

3Prof. Dr.,Hasan Kalyoncu Üniversitesi Sağlık Bilimleri Fakültesi, Gaziantep, Türkiye, E-posta: nermin.olgun@hku.edu.tr , Tel: (0342) 211 80 80, ORCID: 0000-0002-87044588

Geliş Tarihi: 06 Kasım 2020, Kabul Tarihi: 12 Nisan 2021

*Bu çalışma 6-11 Ekim 2020 tarihlerinde Türkiye'de online gerçekleştirilen 22. Ulusal iç̧ Hastalıkları kongresinde sözel bildiri olarak sunulmuştur.

Atıf/Citation: Sazak Y, Aytekin Kanadlı K, Olgun N. Yoğun Bakım Hastalarında Müzik Uygulamasının Fizyolojik ve Psikolojik Etkileri: Sistematik Derleme. Hacettepe Üniversitesi Hemşirelik Fakültesi Dergisi 2021;8(2):203-212. DOI: 10.31125/hunhemsire.968858 


\section{GiRiş}

Yoğun Bakım Üniteleri (YBÜ), yaşamı tehdit altında olan bireylere, en üst düzeyde fayda sağlamak amacıyla kullanılan içinde birçok yaşam kurtarıcı teknolojik araç gereçlerin bulunduğu, sürekli hasta izleminin yapıldığı, multidisipliner yaklaşımın zorunlu olduğu bölümlerdir. YBÜ'lerinin temel hedefi; hastaların yaşam fonksiyonlarının desteklenmesi, hastalığı oluşturan nedenlerin tedavi edilmesi, oluşabilecek komplikasyonların engellenmesi ve yaşam kalitesinin arttırılmasıdır ${ }^{1,2}$

Yoğun bakıma ihtiyacı olan hastalar; organ veya organ fonksiyonlarının kısmi ya da tamamen kaybedildiği durumlarda yaşamları risk altında olan, çeşitli destekleyici tıbbi araçların yardımına gereksinim duyan ve sürekli izlenmesi gereken hastalardı ${ }^{3,4}$. Yoğun bakımdaki hastaların çoğu mekanik ventilasyon desteğine intiyaç duyarlar. Mekanik ventilasyon, hastalar için hayat kurtarıcı bir tedavi olmasına rağmen hastalarda fizyolojik ve psikolojik sorunlara neden olmaktadır ${ }^{5}$. Aynı zamanda YBÜ'lerinde ki hastalar için; uygulanan invaziv girişimler, uzun süre hareketsiz kalma, iletişim zorlukları, rutin uygulanan hemşirelik bakımları, uykusuzluk, çevresel faktörlerde fizyolojik ve psikolojik sorunlara neden olmaktadır6-9.

Yoğun bakım ünitesinde yatan hastaların yaşadıkları ağrı deneyiminin yönetiminde çeşitli analjezikler, hastanın durumunun ya da ortamın yarattığı stres ve anksiyetenin giderilmesinde ise genellikle sedasyon tedavisi uygulanmaktadır ${ }^{9,10}$. Fakat bu uygulamalar her zaman tek başına etkili olmamakta çeşitli komplikasyonlara ve maliyetlerin artmasına neden olmaktadır ${ }^{11}$. Analjeziklerin ve sedatiflerin kullanılamadığı ya da etkilerinin yetersiz kaldığı durumlarda ya da farmakolojik ilaç gereksinimlerini azaltmak için nonfarmakolojik yöntemler kullanılmaktadır ${ }^{10}$. Bu nonfarmakolojik yöntemlerden biri de müziktir.

Müzik, insanoğlunun tarihi kadar eski bir geçmişe ve hayatımızda da önemli bir yere sahiptir. Müzik; toplumun ruhsal yapısını olumlu yönde etkileyen bir sanat dalıdır. Müzikle tedavi yöntemleri; birçok medeniyette çeşitli hastalıkların tedavisinde kullanılmıştır ve halen de kullanılmaktadır ${ }^{12,13}$. Müzik terapi, ise bireylerin fiziksel, psikolojik, sosyal ve zihinsel ihtiyaçlarını karşılamada müziği ve müzik aktivitelerini kullanan uzmanlık dalıdır ${ }^{14}$. Insanlık tarihinin her döneminde yer alan ve evrensel olan müziğin insan sağlığı üzerine birçok olumlu etkilerinin gözlenmesi, tarih boyunca müzik ile tedavinin her toplumda yaygın olarak kullanılmasına neden olmuştur ${ }^{15-17}$. Müziğin tedavi amacıyla kullanıldığı en eski medeniyetlerin başında Sümerler, Babiller, Asurlar, Şamanlar, Çinliler, Eski Mısır ve Antik Yunanlılar gelmektedir. Milattan sonra da Endülüs Emevi, Selçuklu ve Osmanlı döneminde şifahanelerde müzik farklı ruhsal ve bedensel rahatsızlıkların tedavisinde yaygın olarak kullanılmıştır ve halen tüm dünyada tıp alanında kullanılmaya devam edilmektedir ${ }^{16,18,19}$.

Müzik tedavisinin insan vücudu üzerinde fizyolojik ve psikolojik olarak birçok olumlu etkisi vardır. Ruhsal hastalıkların oluşumunda etkisi olan ve kişinin duygusal durumunu düzenleyen serotonin, dopamin, adrenalin, testosteron gibi hormonlar üzerinde olumlu etkisi bulunmaktadır ${ }^{12,14}$. Yapılan çalışmalarda; müziğin ağrı ve anksiyeteyi azalttığı, yaşam bulguları üzerinde olumlu etkiler meydana getirdiği ${ }^{20,21}$, insanların yaşam kalitesini yükselttiği görülmektedir ${ }^{22}$. Uykusuzluğu hafifletici etkileri olduğu da bilinmektedir ${ }^{12}$. Bu özelliklerine bağlı olarak müzik insanlarda terapi faktörü olmaktadır ${ }^{14}$.

Ülkemizde müzik terapi uygulaması; 27 Ekim 2014 tarihli Resmi Gazete'de yayımlanarak yürürlüğe giren Geleneksel ve Tamamlayıcı Tıp Uygulamaları Yönetmeliği kapsamında sertifikalı eğitim alanı olarak belirlenmiştir. Yönetmeliğe göre setifika programına katılım için; tabip, sağlık meslek mensubu veya müzik alanı lisans mezunu olma şartı bulunmaktadır ${ }^{23}$.

Hemşireler, YBÜ’lerinin vazgeçilmez bir ekip üyesidir. Hastaların tanılamasını yapmak, hastaları sürekli izlemek, kaliteli ve ileri yoğun bakım ve tedavi girişimleri uygulamakla beraber koruyucu, iyileştirici ve rehabilite edici girişimleri uygulamaktan da sorumludurlar ${ }^{24}$.

Yoğun bakım hemşireliğinin amacl; bireyi holistik bir yaklaşımla değerlendirerek fizyolojik, psikolojik, emosyonel ve sosyal dengesinin en iyi duruma gelmesinde yardımcı olmaktır ${ }^{25}$. Hemşirelerin müzik terapi konusunda sertifika eğitimlerini tamamlayarak hastalara uygulayacakları müzik terapi uygulamaları, bakım kalitesinin arttırılmasında ve semptom yönetiminde etkili olacaktır. Ayrıca; müzik terapinin herhangi bir yan etkisinin olmaması, ek bir maliyet getirmemesi, kullanım kolaylığı ve faydaları açısından hemşireler tarafından nonfarmakolojik bir girişim olarak hastaların bakım ve tedavi protokollerinde kullanılmasını mümkün kılmaktadır ${ }^{26}$. Alves ve arkadaşlarının yaptığı sistematik derlemede; müzik uygulamalarının yoğun bakım hastalarında fizyolojik ve psikolojik semptomların azaltılmasında etkili olduğunu ve hemşirelik uygulamalarında kullanılmasının yararlı olacağını belirtmişlerdir ${ }^{27}$.

\section{Araştırmanın Amacı}

Müzik terapi uygulamasının yoğun bakım hastaları üzerinde kullanımının sınırı olduğu görülmektedir. Ülkemizde de aktif olarak müzik terapi uygulaması hastalarda uygulanmamakta ve bu konu hakkında yapılan çalışmalar sınırlıdır. Bu sistematik derleme ile yoğun bakım hastalarında müzik uygulamalarının hastalar üzerindeki fizyolojik ve psikolojik etkilerinin belirlenmesi amaçlanmıştır. Bu çalışma ile yoğun bakım hastalarında uygulanan müzik uygulamasının hastalar üzerindeki fizyolojik ve psikolojik etkileri nelerdir? sorusuna yanıt aranmıştır.

\section{GEREÇ ve YÖNTEM}

\section{Araştırmanın Türü}

Bu çalışmada; sistematik derleme niteliğinde hazırlanmış olup, sistematik derleme protokolünün oluşturulması ve makalenin yazımında PRISMA Bildirimi (Preferred Reporting Items for Systematic review and Meta-Analysis Protocols/Sistematik Derleme ya da Meta-Analiz Araştırma Raporunun Yazımında Bulunması Gereken Maddelerle Illgili Kontrol Listesi) izlenmiştir28,29.

\section{Araştırma Evren ve Örneklemi}

Araştırmaya dahil edilme kriterleri olarak PICOS (Population, Intervention, Compare, Outcome, Study design) temel 
alınarak; 18 yaş ve üstü psikolojik bir sorunu olmayan yoğun bakım hastalarını kapsayan, çalışmalarda müdahale grubunda sadece müzik uygulandığı hastaları kapsayan ve müziğin hastalar üzerinde fizyolojik ve psikolojik etkilerinin sonuçlarını araştıran, yayın dili Türkçe veya İngilizce olan, tam metnine ulaşılabilen, 01 Ocak 2014-25 Eylül 2019 yılları arasında yayınlanan ve araştırma makalesi olan, yarı deneysel, deneysel, randomize kontrollü tasarımda olan çalışmalar dahil edilmiştir. Dışlanma kriterleri olarak ise; 18 yaş altı hastaları kapsayan, yoğun bakım dışındaki hastaları kapsayan, yarı deneysel, deneysel, randomize kontrollü tasarımda olmayan çalışmalar ve müzik dışında ek uygulamaları içeren çalışmalar araştırma kapsamına alınmamıştır.

\section{Veri Toplama Araçları}

Araştırmacılar tarafından veri çekme formu oluşturularak verilerin özetlenmesi sağlandı. Veri çekme işlemi birinci araştırmacı tarafından yapıldı ve ikinci araştırmacı tarafından kontrol edildi. Veri çekme formunun içeriği; çalışmaların yazarları, yılı, araştırmanın yapıldığı yer, hangi yoğun bakım ünitesi olduğu, yaş ortalamaları, cinsiyetleri, araştırma tasarımı, örneklemi, çalışmanın amacı, kullanılan ölçüm araçları, uygulama özellikleri, müziğin türü ve uygulamanın sonuçları ile ilgili bilgilerden oluşturuldu.

\section{Tarama Stratejisi}

Yoğun bakımda tedavi gören hastalarda müzik uygulamasının hastalar üzerindeki fizyolojik ve psikolojik etkilerini belirleyebilmek için yapılan çalışmada 1 Ocak 2014-25 Eylül 2019 arasında yayınlanmış olan 1492 makale taranmıştır. Taramalar birinci araştırmacı tarafından yapılmış, ikinci araştırmacı tarafından hataları kontrol altına almak için tekrarlanmış ve kontrol edilmiştir. Taramalarda "intensive care units", "music therapy", "music", "critical care" MesH terimleri kullanılarak CINAHL 128, Pubmed 195, MEDLINE 132, Ovid 32, Web of Science 134, Complementary Index 97, Science Direct 48, Academic Search Complete 186, Scopus 63 veri tabanlarında tarama yapılmıştır. Türkçe olarak "yoğun bakım", "müzik terapi" ve "müzik" anahtar kelimeleri kullanılarak Google Akademik ve ULAKBiM Ulusal Veri Tabanları (UVT) ile tarama yapılmıştır. Taramada kullanılan anahtar kelimeler Tablo 1'de verilmiştir. Taranan çalışmalar EndNote X8 programı kullanılarak birleştirilmiş ve tekrar eden çalışmalar belirlenerek ayıklanmıştır.

Tablo 1. Taramada Kullanılan Anahtar Kelimeler

\begin{tabular}{|l|l|}
\hline İngilizce Anahtar Sözcükler & Türkçe Anahtar Sözcükler \\
\hline Intensive Care Units AND & $\begin{array}{l}\text { Yoğun Bakım VE Müzik } \\
\text { Terapi }\end{array}$ \\
\hline Intensic & Yoğun Bakım VE Müzik \\
Music Therapy & \\
\hline $\begin{array}{l}\text { Critical Care AND Music } \\
\text { Therapy }\end{array}$ & \\
\hline Critical Care AND Music & \\
\hline
\end{tabular}

\section{Çalışmaların Seçimi}

Bu derlemeye Türkçe ve İngilizce olarak yayınlanmış, yoğun bakım hastalarını kapsayan ve bu hastalarda sadece müzik uygulamaları yapılan ve müdahale sonuçlarını araştıran yarı deneysel, deneysel, randomize kontrollü tasarımda olan çalışmalar dahil edilmiştir. Çalışmaların belirlenmesi iki araştırmacı tarafından bağımsız olarak gerçekleştirilmiş, çalışmalar hakkında fikir ayrılığı olması durumunda tartışılarak ortak karara varılmıştır. Özet, başlık ve tam metni incelenen 12 çalışma araştırmaya dahil edilmiştir 5,26,30-39. Araştırmaya dahil edilen çalışmaların seçim aşaması Şekil 1 'de verilmiştir.

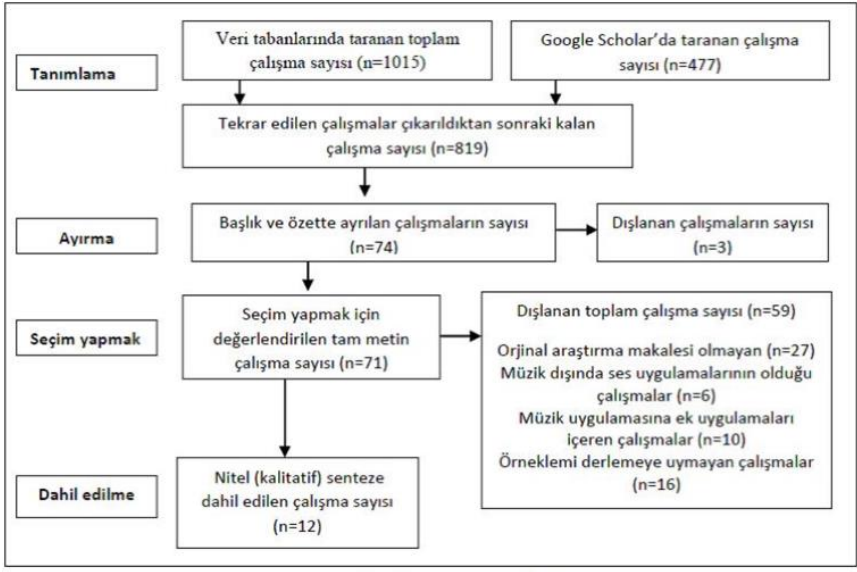

Şekil 1: Çalışmaların seçimi ve dahil edilme süreci akış şeması

\section{Çalışmaların Metodolojik Kalitesinin Değerlendirilmesi}

Araştırmaların kalite değerlendirmesi birinci ve ikinci araştırmacı tarafından bağımsız olarak yapılmıştır. Daha sonra araştırmacılar tarafından bağımsız olarak yapılan değerlendirmeler karşılaştırılarak farklı görüşlerde ortak karara varılmıştır. Bu derlemede çalışmaların metodolojik kalitesini değerlendirmek için; Nahcivan ve Seçginli tarafından Türkçe'ye uyarlanan Joanna Briggs Enstitüsü (JBI) tarafından geliştirilmiş deneysel ve yarı deneysel araştırmaların metodolojik kalitesini değerlendirme aracı olan Joanna Briggs Institute-Meta Analysis Statistic Assessment and Review Instrument (JBI-MAStARI) kullanılmıştır. Deneysel ve Yarı Deneysel Araştırmalar Kontrol Listesi için Cronbach's alfa katsayısı 0,68'dir. Bu değerlendirme aracı 10 maddeden oluşmakta ve toplam puan 0-10 arasında değişmektedir. Her madde için "Evet "cevabı 1 puan, "Hayır", "Belirtilmemiş" ve "Uygun değil" cevabı 0 puan olarak değerlendirilir. Puanlamanın yüksek olması araştırmada metodolojik olarak kalite yüksekliğini belirtmektedir. ${ }^{40}$

\section{Verilerin Analizi}

Verilerin analizinde veri çekme formu kullanıldı. Araştırma verileri heterojen özellikte olduğu için verilerle ilgili meta analiz yapılmadı. Araştırma sonuçları sentezlenerek tanımlayıcı veriler ve tablo olarak sunulmuştur.

\section{Araştırmanın Etik Boyutu}

Sistematik derleme çalışmasına dahil edilen araştırmalarda; araştırmacılara yönelik herhangi bir zarar verme riski bulunmayıp, derlemeye dahil edilen araştırmalar kaynak olarak belirtilmiştir.

\section{Araştırmanın Sınırlılıkları}

$\mathrm{Bu}$ derlemenin sınırlılıkları; araştırma kapsamına alınan çalışmaların farklı yoğun bakım ünitelerinde yapılması, ventilasyon desteğinde olan ve olmayan hastaları kapsaması nedeni ile örneklem grubunun heterojen olması, 
çalışmaların örneklem sayıları, yayın dili Türkçe ve İngilizce olan makaleleri kapsaması, kullanılan müzik türü ve sürelerinin farklı olması, kullanılan ölçüm araçlarının farklı olması ve tüm çalışmaları içermemesi olarak yorumlanabilir. Ayrıca; sistematik derleme kapsamındaki çalışmaların çoğunda müzik uygulamalarının bu konuda eğitim almış sertifikalı uzmanlar tarafından uygulanıp uygulanmadığı hakkında bilgi verilmemiştir. Bu nedenle çalışmaların verileri ile ilgili meta-analiz yapılmamış sonuçlar yüzde ve tablo olarak sunulmuştur. Daha özelleştirilmiş sonuçlar elde edilememiştir.

\section{BULGULAR}

\section{Tarama Bulguları}

Araştırma tasarımına yönelik yapılan taramada 1492 veriye ulaşılmış olup, 673 veri tekrar eden çalışmalar (duplikasyon) olması nedeni ile çıkarılmıştır. Araştırmacılar tarafından geriye kalan 819 çalışmanın başlık ve özeti incelenmiş ve 71 çalışma tam metni incelenmek üzere seçilmiştir. Seçilen çalışmalardan; 59 tanesi araştırmaya dahil edilme kriterlerine uymadığı için sistematik derlemeye dahil edilmemiştir. Tam metni incelenen 12 çalışmada araştırmaya dahil edilmiştir. Araştırma akış şeması Şekil 1'de verilmiştir.

\section{Çalışmaların Metodolojik Kalitesinin Değerlendirilmesi Sonuçları}

Sistematik derlemeye dahil edilen araştırmaların JBIMAStARI aracı ile değerlendirilmesi sonucu en düşük kalite puanı 4, en yüksek kalite puanı ise 9 olarak belirlenmiştir. Makalelerin ortalama kalite puanı 6,4'tür. Her bir araştırmanın kalite puanları Tablo 2'de yer almaktadır.

\section{Çalışmaların Özellikleri}

Sistematik derlemeye dahil edilen çalışmaların örneklemini 18-83 yaş arası yoğun bakım ünitesinde yatan mekanik ventilasyon desteği alan ve almayan 1152 hasta oluşturmaktadır. Araştırmalarda örneklem sayısının en az 22, en fazla 500 olduğu görülmektedir. ${ }^{26,35}$ Çalışmalar; 20092017 yılları arasında Türkiye (6), Tayvan (2), Amerika (3), Danimarka'da yapılmış ve 2014-2019 yıllarında yayınlanmıştır. Derlemeye dahil edilen çalışmaların; 7'si randomize kontrollü, 2'si deneysel çalışma, 1'i tek gruplu öntest-sontest, 2'side yarı deneysel olan toplam 12 çalışmadan oluşmaktadır. Çalışmaların; 6'sı genel yoğun bakım, 2'si cerrahi yoğun bakım, 2'si koroner yoğun bakım, 1'i kalp damar cerrahi yoğun bakım, 1'i de anesteziyoloji ve reaminasyon ünitesinde yapılmıştır (Tablo 2 ).

Sistematik derlemeye dahil edilen çalışmalarda araştırmacılar tarafından oluşturulmuş hasta tanılama formları, tıbbi kayıt formları ile kişisel ve demografik bilgiler toplanmıştır. Ayrıca çalışmalarda; fizyolojik parametreler ölçüm formları, yüz anksiyete ölçeği (FAS), Richmond Ajitasyon Sedasyon Skalası (RASS), Ramsey Sedasyon Skalası (RSS), davranışsal ağrı ölçeği, yoğun bakım ağrı gözlem ölçeği, Görsel Analog Skala (VAS), STAI-1(State-Trait Anxiety Inventory) Durumluk Kaygı Envanteri, STAI-2 Sürekli Kaygı Envanteri, Genel Konfor Ölçeği (GKÖ), APACHE III (Akut Fizyoloji ve Kronik Sağlık Değerlendirmesi), Anksiyete İçin Vizüel Analog Skala (VAS-A), Dispne İçin Vizüel Analog Skala (VAS-D), Amerikan Yoğun Bakım Hemşireler Birliğinin
Sedasyon Değerlendirme Ölçeği, Richard-Campbell uyku Ölçeği (RCSQ), Yaygın anksiyete bozukluğu-7 (GAD-7) ölçeği, $\mathrm{ET}_{S}$ (Duygusal termometreler), nümerik değerlendirme ölçeği (NRS), Yüz ifadesi skalası, C-STAI Anksiyete Ölçeği, Serum Kortizon Ölçümü, Yüz Ağrı Skalası, Glaskow Koma Skalası (GKS), Modifiye Edilmiş Gülen Yüz Skalası kullanılmıştır (Tablo 2).

Sistematik derlemeye dahil edilen çalışmalarda; sistolik kan basıcı (SKB), diyastolik kan basıncı (DKB), ortalama arter basıncı (OAB), nabız hızı, solunum hızı, oksijen saturasyonu değerleri $\left(\mathrm{SPO}_{2}\right)$, anksiyete düzeyi, sedasyon düzeyi, ağrı, konfor düzeyi, dispne durumu, ventilasyondan ayırma süresi, subjektif uyku kalitesi, serum kortizon ölçümü, mekanik ventilasyon tidal volümü ve opioid kullanımı değerlendirilmiştir.

Çalışmalarda uygulanan müzik süreleri 20-60 dk. arasında değişmektedir. Müzik uygulama sürelerinin; bir çalışmada $20 \mathrm{dk}$., yedi çalışmada $30 \mathrm{dk}$., bir çalışmada $40 \mathrm{dk}$, bir çalışmada $50 \mathrm{dk}$. ve iki çalışmada $60 \mathrm{dk}$. olarak uygulandığı görülmüştür. Müzik uygulamaları; canlı müzik (1 çalışma), müzik yastığı kullanılarak (1 çalışma), tavana asılmış hoparlör ile müziğin ortama verilmesi (1 çalışma) ve kulaklık aracılığı (9 çalışma) ile gerçekleştirilmiştir.

Golino ve arkadaşlarının çalışmasında; müdahale uygulaması müzik terapisti tarafından yapılmıştır ${ }^{36}$. Derlemeye dahil edilen 9 çalışma hemşireler tarafından yapılmıştır. Derlemeye dahil edilen çalışmaların üç tanesinde müzik seçimi için uzman görüşü alınarak müzik türüne karar verilmiş, iki çalışmada MusiCure Dreams albümüne ait yoğun bakım hastaları için geliştirilmiş müzik tercih edilmiştir. Diğer çalışmalarda araştırmacının belirlediği müzik türü ya da hasta seçimine göre müzik seçimi yapılmıştır. Dinletilen müziklerle ilgili bilgiler Tablo 2'de yer almaktadır.

\section{Uygulama Sonuçları}

Sistematik derlemeye dahil edilen yedi çalışmada SKB ve DKB ölçümleri değerlendirilmiştir ${ }^{5,26,30,31,33-35}$. SKB değerlendirilen çalışmaların; \%85.7'sinde $\quad(6$ çalışma) $)^{5,26,30,31,33,35}$, DKB değerlendirilen çalışmaların \%57.1'inde (4 çalışma) $)^{5,26,31,35}$ müziğin kan basıncı üzerinde olumlu etkisi olduğu saptanmış ve bu fark istatistiksel olarak anlamlı bulunmuştur. $O A B^{\prime} n ı n$ değerlendirildiği üç çalışmada ise $\mathrm{s}^{31,37,39}$; müzik uygulamasının çalışmaların \%33.3'ünde (1 çalışma) olumlu etkisi olduğu saptanmıştır ${ }^{31}$. Nabız hızı; sistematik derlemeye dahil edilen 10 çalışmada değerlendirilmiştir ${ }^{5,26,30,31,33-37,39}$. Nabız hızı değerlendirilen çalışmaların \%70'inde (7 çalışma) müzik uygulamalarının nabız hızı üzerinde olumlu etkisi olduğu saptanmış ve bu fark istatistiksel olarak anlamlı bulunmuştur 5,31,33,35-37,39.

Solunum hızı; sistematik derlemeye dahil edilen 6 çalışmada değerlendirilmiştir ${ }^{26,30,31,36,37,39}$. Solunum hız। değerlendirilen çalışmaların \%66.7'sinde (4 çalışma) müzik uygulamalarının solunum hızı üzerinde olumlu etkisi olduğu saptanmıştır ${ }^{31,36,37,39} . \quad \mathrm{SPO}_{2}$ değeri 9 çalışmada değerlendirilmişs, $26,30,31,34-37,39$ ve çalışmaların \%55.5'inde (5 çalışma) müzik uygulamalarının $\mathrm{SPO}_{2}$ değerini arttırdığı saptanmış ve bu fark istatistiksel olarak anlamlı bulunmuştur ${ }^{26,30,31,35,39}$. Sistematik derlemeye dahil edilen çalışmalara göre; müzik uygulamasının hastalarda kan 
basıncı, solunum hızı, nabız hızı ve $\mathrm{SPO}_{2}$ üzerinde olumlu etkisi olduğu saptanmış ve müziğin neden olduğu herhangi bir olumsuz durum bildirilmemiştir.

Anksiyete; sistematik derlemeye dahil edilen 8 çalışmada değerlendirilmiştir ${ }^{5,30,31,33,35-38 \text {. Anksiyetenin }}$ değerlendirildiği çalışmaların \%87.5'inde (7 çalışma) müzik uygulamasının hastaların anksiyete düzeylerini azalttığı saptanmış bu fark istatistiksel olarak anlamlı bulunmuştur 5,30,31,33,35-37.

Sedasyon düzeyleri; sistematik derlemeye dahil edilen 4 çalışmada değerlendirilmiştir. Sedasyon düzeyi ölçülen tüm çalışmalarda müzik uygulamasının hastaların sedasyon düzeyleri üzerinde olumlu etkileri olduğu saptanmıştır ve istatistiksel olarak anlamlı bulunmuştur $5,26,31,34$.

Ağrı; sistematik derlemeye dahil edilen 7 çalışmada değerlendirilmiştir ${ }^{5,30,34-36,38,39}$. Ağrı düzeyi değerlendirilen çalışmaların \%85.7'sinde (6 çalışma) müzik uygulamasının hastalarda ağrıyı azalttığı saptanmış ve bu fark istatistiksel olarak anlamlı bulunmuştur ${ }^{5,30,34-36,39}$.

Konfor düzeyi (1 çalışma) ${ }^{30}$, dispne durumu (1 çalışma), ventilasyondan ayırma süresi ( 1 çalışma) ${ }^{37}$, subjektif uyku kalitesi ( 1 çalışma) ${ }^{32}$, serum kortizon ölçümü (1 çalışma) $)^{33}$ çalışmalarda değerlendirilmiş ve müzik uygulamasının bu ölçümler üzerinde olumlu etkileri olduğu saptanmıştır $(p<0.05)$.

Mekanik ventilasyon tidal volümü (1 çalışma) ${ }^{39}$ ve opioid kullanımı (1 çalışma) ${ }^{38}$ çalışmalarda değerlendirilmiş ve müzik terapi uygulamaları arasında anlamlı bir ilişki bulunamamıştır.

Sistematik derlemeye dahil edilen çalışmalarda; müzik uygulamasının hastalarda anksiyete, ağrı, dispne düzeyini, sedasyon ihticayıcını azalttığı ve hastaların konfor düzeyini, uyku kalitesini arttırdığı saptanmış olup, çalışmalarda müzik uygulamasının neden olduğu olumsuz bir durum bildirilmemiştir.

\section{TARTIŞMA}

Bu sistematik derlemede, müziğin yoğun bakım hastaları üzerindeki fizyolojik ve psikolojik etkilerinin neler olduğu sorusuna odaklanılmıştır. Dahil edilme kriterlerine uyan 12 çalışma araştırma kapsamına alınmıştır. Araştırma kapsamında incelenen çalışmalar farklı yoğun bakım ünitelerinde, örneklem büyüklüğünde, farklı tanılardaki ventilasyon desteği alan ve almayan hastaları kapsamaktadır. Bu durum sistematik derleme kapsamına alınan çalışmaların örneklemlerin heterojen olmasına neden olmuştur. Uygulamalarda yer alan müzik türleri ve uygulama süreleri çalışmalara göre farklılık göstermektedir.

Çalışmalarda uygulanan müzik süreleri 20-60 dk. arasında değişmektedir. Müzik uygulamaları; canlı müzik (1 çalışma), müzik yastığı kullanılarak (1 çalışma), tavana asılmış hoparlör ile müziğin ortama verilmesi (1 çalışma) ve kulaklık aracılığı ( 9 çalışma) ile gerçekleştirilmiştir.

Golino ve arkadaşlarının çalışmasında; müdahale uygulaması müzik terapisti tarafından yapılmıştır ${ }^{36}$. Derlemeye dahil edilen üç çalışmada müzik seçimi hastalara bırakılırken ${ }^{33,36,37}$, diğer çalışmalarda belirlenen müzikler hastalara dinletilmiştir. Üç çalışmada; müzik türünün seçimi için müzik alanında ihtisaslaşmış kişilere danışılmış30,34,35, iki çalışmada ise; yoğun bakım hastalarında kullanılmak için geliştirilen müzik türü tercih edilmiştir ${ }^{32,38}$. Diğer çalışmalarda müzik türünün seçiminin de konu ile ilgili bir uzman görüşünün olup olmadığı belirtilmemiştir. Müzik uygulamaları için seçilen müzikler çeşitli kaynaklardan elde edilebilir. Bunlar; bilinen ve rahatlama amacıyla ticari olarak üretilen müzik veya özel şirketler tarafından çok sayıda hastane ortamına müdahaleler için özel olarak geliştirilen müzik olarak sınıflandırılabilir. Müzik seçimine hasta karar verecekse hastanın tercihini belirlemek ve yoğun bakım müdahaleleri ile başa çıkmak için en yararlı olacak müzik seçimine rehberlik etmek amacıyla hastaya kısa bir anket uygulanabilir ${ }^{41}$. Bazı araştırmacılar; olumsuz duygu durumların oluşmasını engellemek için terapötik etkili olan uygun müziklerin kullanımını savunmaktadırlar ${ }^{41}$. Derlemeye dahil edilen bir çalışmada müzik terapi uygulaması müzik terapisti tarafından gerçekleştirilmiştir ${ }^{36}$. Amerikan Müzik Terapisi Derneği'ne göre, müzik terapisi; onaylanmış bir müzik terapisi programını tamamlamış olan yetkili bir profesyonel tarafından terapötik bir ilişki içinde kişiselleştirilmiş hedeflere ulaşmak için müzik müdahalelerinin kullanılmasıdır ${ }^{42}$. Bu nedenle müzik terapi uygulamalarının eğitim almış yetkili profesyoneller tarafından verilmesinin daha uygun olduğu görülmektedir. Fakat sağlık personeli tarafından kaydedilmiş olan uygun şartları taşıyan müziğin hastalara dinletilmesinin de hastalarda müzik uygulaması olarak uygulanabileceği belirtilmektedir ${ }^{43}$. Sistematik derlemeye dahil edilen 1 çalışmada müzik uygulaması müzik terapisti tarafından gerçekleştirilmiştir. Diğer çalışmalarda uygulamayı yapan personellerin müzik terapi uygulamalarına yönelik sertifikasyon programlarını tamamlayıp tamamlamadıkları hakkında bilgi yer almamaktadır. Bu nedenle diğer çalışmalarda uygulamalar müzik terapi değil müzik uygulaması olarak uygulanmıştır. Uygulamaları yapan kişilerin bu konuda sertifikasyon programlarını tamamlamış olması müzik uygulamalarının daha etkin ve olumlu sonuçlar elde edilmesi açısından önemlidir.

Sistematik derlemeye dahil edilen çalışmalara göre; müzik uygulamasının hastalarda kan basıncı, solunum hızı, nabız hızı, $\mathrm{OAB}$ ve $\mathrm{SPO}_{2}$ üzerinde olumlu etkisi olduğu saptanmıştır.

Literatürde; müziğin SKB, DKB ve kalp hızı üzerine etkisinin incelendiği mekanik ventilasyon desteğinde olan ve olmayan hastaları da kapsayan bir meta-analiz çalışmasına göre; müzik uygulamasının hastaların kan basıncı ve nabız hızında önemli düzeyde olumlu değişimler meydana getirdiğini saptamıştır ${ }^{20}$. Bradt ve Dileo tarafından yapılan bir sistematik derlemenin sonucuna göre; müzik terapinin hastalarda DKB ve OKB'de azalma için güçlü bir kanıt bulunamamıştır ${ }^{43}$. Ayrıca, müzik dinleme grubunda ve kontrol grubu arasında nabız hızı ve $\mathrm{SPO}_{2}$ için tutarsız sonuçlar bulunmuştur. Liu ve Petrini tarafından yapılan randomize kontrollü çalışmada; müziğin SKB, nabız hızında azalmaya neden olduğu, DKB, solunum hızında her hangi bir etkisinin olmadığı saptanmıştır ${ }^{21}$. 
Tablo 2. Değerlendirilmeye Alınan Çalışmaların Özellikleri

\begin{tabular}{|c|c|c|c|c|c|c|c|}
\hline Yazar/Yıl & $\begin{array}{l}\text { Araştırma } \\
\text { Türü }\end{array}$ & $\begin{array}{l}\text { Çalışmanın } \\
\text { Yapıldığı } \\
\text { Yıl/ Ülke }\end{array}$ & Örneklem Özellikleri & $\begin{array}{l}\text { Kullanılan Ölçüm } \\
\text { Araçları }\end{array}$ & Uygulama Özellikleri & Araştırma Sonuçları & $\begin{array}{l}\text { Kalite } \\
\text { Puan }\end{array}$ \\
\hline $\begin{array}{l}\text { Aghaie B. } \\
\text { ve ark. } \\
(2014)\end{array}$ & $\begin{array}{l}\text { Randomize } \\
\text { kontrollü } \\
\text { çalışma }\end{array}$ & $\begin{array}{l}\text { 2012-2013 } \\
\text { Tayvan }\end{array}$ & $\begin{array}{l}\text { Koroner arter bypass grefti } \\
\text { olmuş kalp damar cerrahisi } \\
\text { yoğun bakım ünitesinde } \\
\text { mekanik ventilasyon } \\
\text { desteği olan hastalar } \\
\text { ( } \mathrm{n}=120) \text {. } \\
\text { Müzik Grubu: } 60 \\
\text { Kontrol Grubu: } 60 \\
\end{array}$ & $\begin{array}{l}\text { *Tıbbi kayıt formları } \\
\text { *Fizyolojik ölçümler } \\
\text { *FAS } \\
\text { *RASS }\end{array}$ & $\begin{array}{l}\text { Müzik grubuna; doğa temelli müzik } 20 \mathrm{dk} \text {. } \\
\text { dinletilmiştir. } \\
\text { Kontrol grubuna kulaklık takılarak sessizce } \\
\text { dinlenmişlerdir. }\end{array}$ & $\begin{array}{l}\text { SKB, DKB, nabız ve solunum hızı, } \mathrm{OAB}, \mathrm{SPO}_{2} \\
\text { müzik grubunda daha iyi. } \\
\text { Anksiyete ve ajitasyon durumları kontrol } \\
\text { grubuna göre azalmıştır. }\end{array}$ & 8 \\
\hline $\begin{array}{l}\text { Yaman } \\
\text { Aktaş Y. } \\
\text { ve } \\
\text { Karabulut } \\
\text { N. (2015) }\end{array}$ & $\begin{array}{l}\text { Deneysel } \\
\text { çalışma }\end{array}$ & $\begin{array}{l}\text { 2010-2013 } \\
\text { Türkiye }\end{array}$ & $\begin{array}{l}\text { Kalp damar cerrahisi yoğun } \\
\text { bakım ünitesindeki } \\
\text { ventilasyon desteği olan } \\
\text { hastalar ( } \mathrm{n}=66) . \\
\text { Müzik Grubu: } 33 \\
\text { Kontrol Grubu: } 33\end{array}$ & $\begin{array}{l}\text { *Hasta tanımlama } \\
\text { formu } \\
\text { *RSS } \\
\text { *Fizyolojik parametre } \\
\text { ölçüm formu } \\
\text { *Davranışsal ağrı } \\
\text { ölçeği } \\
\text { *Yoğun bakım ağrı } \\
\text { gözlem ölçeği }\end{array}$ & $\begin{array}{l}\text { Müzik grubuna aspirasyondan } 20 \mathrm{dk} \text {. önce, } \\
\text { aspirasyon sırasında ve aspirasyondan } 20 \mathrm{dk} \text { sonra } \\
\text { Hüseyni ve Nihavent makamları dinletilmiştir. } \\
\text { Kontrol grubuna; sadece aspirasyon işlemi } \\
\text { yapılmıştır. }\end{array}$ & $\begin{array}{l}\text { Kontrol ve deney grubunda } \mathrm{SKB} \text {, DKB, } \\
\text { nabız, } \mathrm{SPO}_{2} \text { değerlerinde değişme } \\
\text { gözlenmemiştir. Sedasyon ve ağrı } \\
\text { düzeylerinin müzik müdahale grubunda } \\
\text { daha iyi düzeyde olduğu tespit edilmiştir. }\end{array}$ & 6 \\
\hline $\begin{array}{l}\text { Çiftçi H. } \\
\text { ve Öztunç } \\
\text { G. (2015). }\end{array}$ & $\begin{array}{l}\text { Kendinden } \\
\text { kontrollü ve } \\
\text { deneysel } \\
\text { çalışma }\end{array}$ & $\begin{array}{l}\text { 2009-2011 } \\
\text { Türkiye }\end{array}$ & $\begin{array}{l}\text { Genel yoğun bakım } \\
\text { ünitesinde SVO tanısıyla } \\
\text { yatan, bilinci açık hastalar } \\
(\mathrm{n}=72)\end{array}$ & $\begin{array}{l}\text { *Hasta tanımlama } \\
\text { formu } \\
\text { *Vital Bulgular Formu } \\
\text { * VAS } \\
\text { *Yüz Ifadesi Skalası } \\
\text { *STAI-1 } \\
\text { *STAI-2 } \\
\text { *GKÖ }\end{array}$ & $\begin{array}{l}30 \text { dakika rast makamı hastalara kulaklıklar ile } \\
\text { dinletilmiştir. }\end{array}$ & $\begin{array}{l}\text { Müziğin hastaların SKB, ağrı ve anksiyeteyi } \\
\text { azalttığı, } \mathrm{SPO}_{2} \text { ile konfor düzeyini arttırdığı } \\
\text { saptanmıştır. } \\
\text { DKB, nabız hızı, solunum hızında herhangi } \\
\text { bir değişim gözlenmemiştir. }\end{array}$ & 4 \\
\hline $\begin{array}{l}\text { Liang Z. } \\
\text { ve ark. } \\
\text { (2016) }\end{array}$ & $\begin{array}{l}\text { Çapraz } \\
\text { tasarımlı } \\
\text { Randomize } \\
\text { kontrollü } \\
\text { çalışma }\end{array}$ & $\begin{array}{l}\text { Belirtilmemi } \\
\text { A̧merika } \\
\text { Birleşik } \\
\text { Devletleri }\end{array}$ & $\begin{array}{l}\text { Trakeostomisi olan } 4 \text { gün ve } \\
\text { daha uzun süre mekanik } \\
\text { ventilasyon desteğinde } \\
\text { olan genel yoğun bakım } \\
\text { hastaları ( } n=31) \text {. } \\
\text { Çalışmanın ilk gününde; } \\
\text { Müzik ile başlayan grup } \\
\text { ( } n=16) \\
\text { Müziksiz başlayan grup } \\
(n=15)\end{array}$ & $\begin{array}{l}\text { *Tıbbi kayıt formları } \\
\text { *APACHEIII } \\
\text { *Fizyolojik ölçümler } \\
\text { * VAS-A } \\
\text { * VAS-D }\end{array}$ & $\begin{array}{l}\text { Müzik uygulaması } 6 \text { gün boyunca her gün gruplar } \\
\text { arasında değiştirilmiştir. } \\
3 \text { gün müzik uygulama, } 3 \text { gün müziksiz gün olarak } \\
\text { uygulanmışı̈ır. } \\
\text { Müzikler söz içermeyen } 60-80 \text { atım/dk. içeren } \\
\text { müzik mekanik ventilasyondan ayırma denemeleri } \\
\text { sırasında } 60 \mathrm{dk} \text {. kulaklıkla dinletilmiştir. }\end{array}$ & $\begin{array}{l}\text { Müzik grubunda nabız ve solunum hızı, } \\
\text { VAS-A, VAS-D de azalma ve günlük } \\
\text { ventilasyondan ayırma süresinde artış } \\
\text { görülmüştür. } \\
\mathrm{SPO}_{2} \text { ve } \mathrm{OAB}^{\prime} \text { da değişiklik görülmemiştir. }\end{array}$ & 7 \\
\hline $\begin{array}{l}\text { Üzelli } \\
\text { YIImaz D. } \\
\text { ve ark. } \\
(2016)\end{array}$ & $\begin{array}{l}\text { Randomize } \\
\text { kontrollü } \\
\text { çalışma }\end{array}$ & $\begin{array}{l}\text { Mayıs- } \\
\text { Ağustos } \\
2013 \\
\text { Türkiye }\end{array}$ & $\begin{array}{l}\text { Anesteziyoloji ve } \\
\text { Reanimasyon Kliniğinde } \\
\text { yatmakta olan, mekanik } \\
\text { ventilasyon desteğinde, } \\
\text { GKS } \geq 9 \text { ve sedasyon tedavisi } \\
\text { uygulanan hastalar }(\mathrm{n}=22) \\
\text { Müzik Grubu: } 11 \\
\text { Kontrol Grubu: } 11\end{array}$ & \begin{tabular}{|lr} 
*Hasta Tanıtım Formu \\
*Yaşamsal $\quad$ Belirtiler \\
$\begin{array}{lr}\text { izlem Formu } \\
\text { *Amerikan } & \text { Yoğun } \\
\text { Bakım } & \text { Hemşireler } \\
\text { Birliğinin } & \text { Sedasyon } \\
\text { Değerlendirme Ölçeği }\end{array}$
\end{tabular} & $\begin{array}{l}\text { Sedasyon tedavisi kesildikten } 30 \mathrm{dk} \text {. sonra kulaklık } \\
\text { ile } 60 \mathrm{dk} \text {. "Sol Majör" besteleri Antonio Vivaldi'ye } \\
\text { ait Klasik Batı Müziği (Barok Dönemi) eserleri } \\
\text { dinlettirilmiştir. } \\
\text { Kontrol grubuna herhangi bir girişimde } \\
\text { bulunulmamıştır. }\end{array}$ & $\begin{array}{l}\text { Müziğin; SKB, DKB ve } \mathrm{SPO}_{2} \text { değerlerini } \\
\text { olumlu yönde etkilediği solunum ve nabız } \\
\text { hızları üzerinde herhangi bir etkiye sahip } \\
\text { olmadığı saptanmıştır. } \\
\text { Sedasyon Değerlendirme Ölçeği alt } \\
\text { ölçeklerinde (ajitasyon, anksiyete, uyku ve } \\
\text { ventilatör uyumu alt ölçekleri) müziğin } \\
\text { olumlu etkisi olduğu saptanmıştır. }\end{array}$ & 7 \\
\hline $\begin{array}{l}\text { Hansen P. } \\
\text { I. ve ark. } \\
(2017)\end{array}$ & $\begin{array}{l}\text { Randomize } \\
\text { kontrollü } \\
\text { çalışma }\end{array}$ & $\begin{array}{l}\text { Şubat-Nisan } \\
2016 \\
\text { Danimarka }\end{array}$ & $\begin{array}{l}\text { Genel yoğun bakım } \\
\text { ünitesinde yatan mekanik } \\
\text { ventilasyon desteğinde } \\
\text { olan veya olmayan GKS } \geq 14 \\
\text { Sedasyon tedavisi almayan } \\
\text { hastalar ( } n=37 \text { ). } \\
\text { Müzik Grubu: } 18 \\
\text { Kontrol Grubu: } 19 \\
\end{array}$ & $\begin{array}{l}* \text { Demografik } \\
\text { Özellikler *Bilgi formu } \\
* \text { RCSQ }\end{array}$ & $\begin{array}{l}\text { Müzik grubu } 30 \mathrm{dk} \text {. Niels Eje tarafından } \\
\text { geliştirilmiş müziği dinlemiştir. } \\
\text { Kontrol grubu standart bakımı alarak dinlenmiş. }\end{array}$ & $\begin{array}{l}\text { Müdahale grubunda uyku skorlarının daha } \\
\text { iyi olduğu belirlenmiştir. } \\
\text { Uyku derinliği }(p=0.02) \\
\text { Uyanma Durumu }(p=0.00) \\
\text { Uyku kalitesi }(p=0.01)\end{array}$ & 7 \\
\hline $\begin{array}{l}\text { Ames N. } \\
\text { ve ark. } \\
(2017)\end{array}$ & $\begin{array}{l}\text { Randomize } \\
\text { kontrollü } \\
\text { çalışma }\end{array}$ & $\begin{array}{l}\text { 2011-2013 } \\
\text { Amerika } \\
\text { Birleşik } \\
\text { Devletleri }\end{array}$ & $\begin{array}{l}\text { Cerrahi yoğun bakım } \\
\text { ünitesinde operasyon } \\
\text { sonrası yoğun bakımda 24- } \\
48 \text { saat kalması beklenen, } \\
\text { entübe olmayan ve GAD- } \\
\text { 7'e göre şiddetli } \\
\text { anksiyetesi olmayan } \\
\text { hastalar ( } \mathrm{n}=59 \text { ). } \\
\text { Müzik Grubu: } 20 \\
\text { Kontrol Grubu: } 21 \\
\end{array}$ & $\begin{array}{l}* \mathrm{GAD}-7 \\
* \mathrm{STAI} \\
* \mathrm{ET}_{\mathrm{S}} \\
* \mathrm{VAS} \\
* \mathrm{NRS}\end{array}$ & $\begin{array}{l}\text { Müzik grubu 4-6 saat arayla } 50 \text { dakika Musi Cure } \\
\text { Dreams albümüne ait müziği dinlemişlerdir. } \\
\text { Kontrol grubu aynı sürelerde sessizce dinlenmişler. } \\
\text { Girişimler en fazla } 48 \text { saat devam etmiştir. }\end{array}$ & $\begin{array}{l}\text { Grublar arasında opioid kullanımı, VAS ve } \\
\mathrm{ET}_{\mathrm{s}, \text {, anksiyete düzeyleri arasında anlamlı }} \\
\text { fark bulunamamıştır. } \\
\text { NRS ölçümlerinin sonuçları müzik } \\
\text { grubunda istatistiksel olarak anlamlı } \\
\text { bulunmuştur }(p=0.037) .\end{array}$ & 7 \\
\hline $\begin{array}{l}\text { Bayındır S. } \\
\text { ve } \\
\text { Koçyiğit F. } \\
(2017)\end{array}$ & $\begin{array}{l}\text { Tek Gruplu } \\
\text { Öntest - } \\
\text { Sontest }\end{array}$ & $\begin{array}{l}2015 \\
\text { Türkiye }\end{array}$ & $\begin{array}{l}\text { Genel yoğun bakım } \\
\text { ünitesinde yatan GKS 6E-9E } \\
\text { olan hastalar }(n=40)\end{array}$ & $\begin{array}{l}\text { *Yüz ifadesi skalası } \\
* \text { Fizyolojik } \\
\text { parametreler ölçüm } \\
\text { formu }\end{array}$ & $\begin{array}{l}\text { Hastalara her gün } 30 \text { dk. süreyle } 3 \text { gün arka arkaya } \\
\text { Klasik Türk Müziği dinletilmiştir. }\end{array}$ & $\begin{array}{l}\text { Nabız hızı, } \mathrm{SPO}_{2} \text { ve solunum } \mathrm{f} \text { değerlerinde } \\
\text { olumlu etkiler saptanırken, ortalama kan } \\
\text { basıncı ve mekanik ventilatördeki tidal } \\
\text { volüm değerlerinde anlamlı bir fark } \\
\text { saptanmamıştır. }\end{array}$ & 4 \\
\hline
\end{tabular}


Tablo 2. Değerlendirilmeye Alınan Çalışmaların Özellikleri (devamı)

\begin{tabular}{|c|c|c|c|c|c|c|c|}
\hline Yazar/Yıl & $\begin{array}{l}\text { Araştırma } \\
\text { Türü }\end{array}$ & $\begin{array}{l}\text { Çalışmanın } \\
\text { Yapıldığı } \\
\text { Yıl/ Ülke }\end{array}$ & Örneklem Özellikleri & $\begin{array}{l}\text { Kullanılan Ölçüm } \\
\text { Araçları }\end{array}$ & Uygulama Özellikleri & Araştırma Sonuçları & $\begin{array}{l}\text { Kalite } \\
\text { Puan }\end{array}$ \\
\hline $\begin{array}{l}\text { Lee C. H. } \\
\text { ve ark. } \\
(2017)\end{array}$ & $\begin{array}{l}\text { Randomize } \\
\text { kontrollü } \\
\text { çalışma }\end{array}$ & $\begin{array}{l}\text { 2013-2014 } \\
\text { Tayvan }\end{array}$ & $\begin{array}{l}\text { Genel yoğun bakım } \\
\text { ünitesinde mekanik } \\
\text { ventilasyon desteğinde } \\
\text { olan hastalar ( } n=85) \text {. } \\
\text { Müzik Grubu: } 41 \\
\text { Kontrol Grubu: } 44\end{array}$ & $\begin{array}{l}\text { *Tıbbi kayıt formları } \\
\text { *Fizyolojik ölçümler } \\
\text { * VAS-A } \\
\text { *C-STAI } \\
\text { *Serum Kortizon } \\
\text { Ölçümü }\end{array}$ & $\begin{array}{l}\text { Müdahale grubuna kendi tercihlerine göre Batı } \\
\text { klasik müziği, Çin klasik müziği, doğal seslerin } \\
\text { olduğu müzik, dini müziklerden birisi } 30 \mathrm{dk} \text {. } \\
\text { kulaklıklarla dinletilmiştir. } \\
\text { Kontrol grubu } 30 \mathrm{dk} \text {. kulaklık takılı olarak } \\
\text { dinlenmişlerdir. }\end{array}$ & $\begin{array}{l}\text { Müdahale grubunda DKB hariç SKB, nabız } \\
\text { hızı, kortizon değerleri ve VAS-A kontrol } \\
\text { grubuna göre daha iyi düzeyde olduğu } \\
\text { tespit edilmiştir. }\end{array}$ & 9 \\
\hline \begin{tabular}{|l} 
Citlik \\
Sarıtaş S. \\
ve ark. \\
$(2018)$
\end{tabular} & $\begin{array}{l}\text { Yarı } \\
\text { deneysel } \\
\text { çalışma }\end{array}$ & $\begin{array}{l}\text { 2015-2016 } \\
\text { Türkiye }\end{array}$ & $\begin{array}{l}\text { Koroner yoğun bakımda en } \\
\text { az } 24 \text { saat yatan ve en az } 1 \\
\text { gün daha yatacak olan Mı } \\
\text { geçirmiş hastalar }(n=500) \text {. } \\
\text { Deney grubu }(n=250) . \\
\text { Kontrol grubu }(n=250) \text {. }\end{array}$ & $\begin{array}{l}\text { *Hasta bilgi formu } \\
\text { *Test öncesi kayıt } \\
\text { formu } \\
\text { * VAS }\end{array}$ & $\begin{array}{l}\text { Hastalara } 30 \mathrm{dk} \text {. zirgüle müzik dinletilmiştir. } \\
\text { Kontrol grubuna rutin bakım yapılmıştır. }\end{array}$ & $\begin{array}{l}\text { Müdahale grubundaki hastaların nabız hızı, } \\
\text { kan basınçları, anksiyete ve ağrı düzeyleri } \\
\text { azalmış, } \mathrm{SPO}_{2} \text { artmıştır. }\end{array}$ & 6 \\
\hline $\begin{array}{l}\text { Golino J.A. } \\
\text { ve ark. } \\
(2019)\end{array}$ & $\begin{array}{l}\text { Yarı } \\
\text { deneysel } \\
\text { çalışma }\end{array}$ & $\begin{array}{l}\text { Yıl } \\
\text { Belirtilmemi } \\
\text { ş } \\
\text { Amerika } \\
\text { Birleşik } \\
\text { Devletleri }\end{array}$ & $\begin{array}{l}\text { Genel yoğun bakım } \\
\text { ünitesinde mekanik } \\
\text { ventilasyon desteği } \\
\text { olmayan hastalar }(n=52) .\end{array}$ & $\begin{array}{l}\text { *Demografik } \\
\text { Özellikler Bilgi formu } \\
\text { *Fizyolojik ölçümler } \\
\text { *Anksiyete ve Ağrı } \\
\text { Ölçeği }\end{array}$ & $\begin{array}{l}\text { Müzik müdahalesinde } 2 \text { tür müdahale vardı. } \\
\text { Müdahale tercihi hastaya bırakılmıştır. } \\
\text { 1.Gevşeme müdahalesi: Terapist tarafından gitarla } \\
\text { canlı müzik olarak uygulanmıştır. Hastanın basit } \\
\text { hayaller veya odaklanmış solunum gibi gevşeme } \\
\text { tekniklerine odaklanması istenmiştir ( } n=28) \text {. } \\
\text { 2.Şarkı seçimi müdahalesi: Müzik terapisti } \\
\text { hastanın şarkıyı dinlerken söyleyerek katılmasına } \\
\text { teşvik edilmiştir. ( } n=24) \text {. Müdahaleler } 30 \mathrm{dk} \text {. } \\
\text { sürmüştür. }\end{array}$ & $\begin{array}{l}\text { Müdahale gruplarında; solunum hızı, } \\
\text { nabız, ağrı ve anksiyete düzeylerinde } \\
\text { azalma olduğu tespit edilmiştir. } \\
\mathrm{SPO}_{2} \text { değerlerinde herhangi bir değişim } \\
\text { gözlenmemiştir. }\end{array}$ & 5 \\
\hline $\begin{array}{l}\text { Kurt T. ve } \\
\text { Çelik S. } \\
(2019)\end{array}$ & $\begin{array}{l}\text { Randomize } \\
\text { kontrollü } \\
\text { çalışma }\end{array}$ & $\begin{array}{l}\text { 2016-2017 } \\
\text { Türkiye }\end{array}$ & $\begin{array}{l}\text { Cerrahi yoğun bakım } \\
\text { ünitesinde mekanik } \\
\text { ventilasyon desteği alan } \\
\text { hastalar ( } \mathrm{n}=68 \text { ). } \\
\text { Müzik Grubu: } 34 \\
\text { Kontrol Grubu: } 34\end{array}$ & $\begin{array}{l}\text { *Kişisel bilgi ve veri } \\
\text { kayıt formu } \\
\text { *Yüz Ağrı Skalası } \\
\text { *GKS } \\
\text { *Modifiye Edilmiş } \\
\text { Gülen Yüz Skalası } \\
\text { *RASS }\end{array}$ & $\begin{array}{l}\text { Deney grubuna } 30 \mathrm{dk} \text {. doğa temelli ses terapisi ve } \\
\text { gözlerini kapatma işlemi uygulanmıştır. } \\
\text { Kontrol grubu ise } 30 \mathrm{dk} \text {. gözleri kapalı olarak } \\
\text { dinlenmiştir. }\end{array}$ & $\begin{array}{l}\text { Müzik grubunda hastaların SKB, DKB, nabız } \\
\text { ve solunum hızları, ağrı, ajitasyon ve } \\
\text { anksiyete durumlarında olumlu gelişmeler } \\
\text { saptanmıştır. }\end{array}$ & 7 \\
\hline
\end{tabular}

* FAS (Yüz Anksiyete Ölçeği); VAS (Görsel Analog Skala)

STAI-1 (Durumluk Kaygı Envanteri); STAI-2 (Sürekli Kaygı Envanteri) GKÖ (Genel Konfor Ölçeği)

APACHE III (Akut Fizyoloji ve Kronik Sağlık Değerlendirmesi)

VAS-A (Anksiyete İçin Vizüel Analog Skala)

VAS-D (Dispne Iç̧in Vizüel Analog Skala)

RCSQ (Richard-Campbell uyku Ölçeği); GAD-7 (Yaygın anksiyete bozukluğu ölçeği)

ETS (Duygusal termometreler)

NRS (nümerik değerlendirme ölçeği)

C-STAI (Anksiyete Ölçeği)

GKS (Glaskow Koma Skalası)

SVO (Serebrovasküler Olay) 
$\mathrm{Bu}$ sonuçlar, hastalarda hemodinamik yanıtların altında yatan fizyolojinin karmaşık olduğunu, ventilatör desteğinin yanı sıra ilaçlarında etkisinin olabileceğini göstermektedir ${ }^{43}$. Sistematik derlemeye dahil edilen çalışmaların büyük çoğunluğunda müziğin ağrıyı azaltıcı etkisi olduğu saptanmıştır. Literatürde yapılan çalışmalarda da müziğin ağrıyı azaltmada etkili olduğu görülmektedir21,44-46. Müzik; insanlarda duyguları uyarması ile otonomik birçok değişikliğin başlamasına neden olur. Kohlea, akustik bilgiyi, işitsel kortekste nöral aktiviteye dönüştürür, anlam ve duygular uyarılır ${ }^{18}$. Müzik uygulaması; serebrumda sağ hemisferi uyararak limbik sistemi etkiler ve psikofizyolojik yanitlara neden olur. Bunun sonucunda; enkefalin, endorfin salınımına ve parasempatik sistemin aktive olmasını sağlar ${ }^{10}$. Psikofizyolojik yanıtın oluşması ile hastalarda ağrı ve streste azalma sonucunda yaşam bulguları üzerinde de olumlu etkiler oluşturur. Bu nedenle; müzik uygulamasının yoğun bakım hastalarında yaşam bulguları ve ağrı üzerine olumlu etkileri olan bir uygulama olduğu söylenebilir.

Sistematik derlemeye dahil edilen çalışmaların büyük çoğunluğunda müzik uygulamasının hastaların anksiyete düzeylerini azalttığı saptanmıştır Wong ve arkadaşları tarafından yapılan çalışmada; ventilatör desteğinde olan 20 hastaya uygulanan müzik terapi uygulaması sonrası anksiyete düzeylerinde azalma sağlanırken, kan basıncı ve solunum hızında herhangi bir fark saptanamamıştır. Bunun nedenin ise; örneklem grubunun küçük olmasından kaynaklanabileceğini belirtmişlerdir ${ }^{47}$. Chlan ve ark. tarafından yapılan randomize kontrollü çalışmada; müziğin mekanik ventilasyon desteği olan hastalarda anksiyeteyi ve sedatif ilaç kullanımını azalttığını belirtmişlerdir ${ }^{48}$.

Sistematik derlemeye dahil edilen 4 çalışmada hastaların sedasyon düzeyleri değerlendirilmiştir. Sedasyon düzeyi ölçülen tüm çalışmalarda müzik terapi uygulamasının hastaların sedasyon düzeyleri üzerinde olumlu etkileri olduğu saptanmıştır ve istatistiksel olarak anlamlı bulunmuştur $5,26,31,34$. Bradt ve Dileo tarafından yapılan sistematik derlemede meta analiz sonuçlarına göre; hastaların sedasyon skoru müzik müdahale grubunda kontrol grubuna göre anlamlı derecede daha yüksek bulunmuştur. Müdahale grubundaki hastaların sedatif ve analjezik ilaç kullanımının kontrol grubundaki hastalara göre daha az olduğunu belirtmişlerdir ${ }^{43}$. Müziğin parasempatik sistemi aktive etmesi, endorfin ve enkefalin salınımı ile hastaların anksiyete düzeyinde ve sedatif kullanımında azalma meydana gelmektedir ${ }^{10}$. Sistematik derlemeye dahil edilen çalışmalarda ve literatürde müziğin anksiyete ve sedasyon üzerinde olumlu etkileri olduğu bildirilmiştir. Bu nedenle; müzik uygulaması hastaların anksiyete düzeylerinin ve sedatif ilaç kullanımında azaltılmasında etkili bir yöntem olduğu söylenebilir.

Konfor düzeyi (1 çalışma), dispne durumu (1 çalışma), ventilasyondan ayırma süresi (1 çalışma), subjektif uyku kalitesi (1 çalışma), serum kortizon ölçümü (1 çalışma) çalışmalarda değerlendirilmiş ve müzik uygulamasının bu ölçümler üzerinde olumlu etkileri olduğu saptanmıştır $(p<0.05)$. Müzik terapi uygulaması ağrı ve anksiyete düzeyindeki azaltıcı etkisi ile hastaların konfor seviyesinin artmasına neden olmaktadır. Yapılan çalışmalarda müzik tedavisinin hastalarda fizyolojik ve psikolojik olarak olumlu etkileri ile uykusuzluğu hafifletici etkisi olduğu gösterilmiştir ${ }^{12,49}$. Kardiyak operasyon geçiren hastalarda yapılan randomize kontrollü bir çalışmada, müzik terapi uygulamasının hastaların serum kortizol düzeylerini düşürdüğü saptanmıştır ${ }^{50}$.

Hemşire yoğun bakımdaki hastayı holistik açıdan değerlendirerek; hastanın fiziksel, emosyonel, sosyal ve psikolojik açıdan en iyi duruma gelmesine yardımcı olmaya çalışır. Holistik bakımı sürdürürken nonfarmakolojik bir yöntem olan müzik uygulamalarından yararlanabilir. Müzik uygulamasının etkin sonuçlarının olması için; sertifikaya sahip hemşireler tarafından uygulanması gerekmektedir. Derlemeye dahil edilen çalışmaların 9 tanesi hemşirelik alanında yapıımış çalışmalar olup, uygulayan kişilerin müzik uygulama ile ilgili sertifika yada eğitim alıp almadıkları belirtilmemiştir. Yapılan çalışmalarda müzik uygulamasının hastalarda fiziksel ve psikolojik olarak olumlu etkileri saptanmıştır ve neden olduğu olumsuz durum bildirilmemiştir. Bu nedenle hemşirelerin müzik terapi sertifika programlarına katılarak yada müzik terapi eğitimi olan diğer hemşirelerle işbirliği içinde bakım planına müzik uygulamasını entegre etmesi uygun olacaktır.

\section{SONUÇ ve ÖNERILER}

Sistematik derleme kapsamında incelenen çalışmalarda; müzik uygulamasının yoğun bakım hastalarında yaşam bulguları, anksiyete, sedasyon düzeyleri, ağrı, uyku kalitesi ve konfor düzeylerinde olumlu etkileri olduğunu göstermektedir. Çalışmalarda müzik uygulamasının hastalar üzerinde herhangi bir zararlı etkisine rastlanmamıştır. Bu nedenle yoğun bakımda çalışan hemşirelerin müzik uygulamaları konusunda sertifikasyon programlarına katılımları sağlanarak bu uygulamanın bakım planına dahil edilmesi hastalar açısından yararlı bir uygulama olacaktır. Hemşirelik eğitimi ders müfredat programlarında müzik uygulamaları ile ilgili dersler yer alabilir. Sağlık yöneticileri tarafından; müzik terapi uygulamaları kapsamında sertifikasyon programları düzenlenerek müzik terapi uygulama alanlarının genişletilmesi ve aktif olarak kullanılması sağlanmalıdır. Müzik terapi uygulamaları ile ilgili daha kapsamlı çalışmalar için kortizol ölçümleri, katekolamin düzeyleri ölçülerek randomize kontrollü, deneysel çalışmalar yapılabilir.

Etik Kurul Onayı: -

Çıkar Çatışması: Yoktur.

Finansal Destek: Bildirilmemiştir.

Katılımcı Onamı: -

Yazar katkıları:

Araştırma dizaynı: YS, KAK, NO

Veri toplama: YS, KAK

Literatür araştırması: YS, KAK, NO

Makale yazımı: YS, KAK, NO

Teşekkür: -

Ethics Committee Approval: -

Confict of Interest: Not reported.

Funding: None.

Exhibitor Consent: -

Author contributions:

Study design: YS, KAK, NO 
Data collection: YS, KAK

Literature search: YS, KAK, NO

Drafting manuscript: YS, KAK, NO

Acknowledgement: -

\section{KAYNAKLAR}

1. Wojnicki-Johansson G. Communication between nurse and patient during ventilator treatment: Patient reports and RN evaluations. Intensive Crit Care Nurs. 2001;17(1):29-39.

2. Terzi B, Kaya N. Yoğun bakım hastasında hemşirelik bakımı. Yoğun Bakım Dergisi. 2011;1:21-5.

3. Hatipoğlu S. Cerrahi yoğun bakım hemşireliği ilkeleri. Gülhane Tıp Dergisi 2002;475.

4. Çelik S. Yoğun bakım ünitesinde hasta kabul ve taburculuk kriterleri. Yoğun Bakım Hemşireliği Dergisi. 2007;11(2):96-101.

5. Kurt T, Çelik S. Yoğun bakım hastalarını mekanik ventilasyondan ayırma sürecinde doğa temelli ses terapisinin etkisi. Cukurova Med J. 2019;44(1):119.

6. Dedeli Ö, Akyol AD. Yoğun bakım hastalarında psikososyal sorunlar. Yoğun Bakım Hemşireliği Dergisi. 2008;12(1):26-32.

7. Erden S. Yoğun bakımda ağrı yönetiminde hemşirenin anahtar rolleri. Van Tıp Dergisi. 2015;22(4):332-6.

8. Demir Y. Yoğun bakım ünitesinde ağrı deneyimi ve ağrının değerlendirilmesi: Literatür incelemesi. DÜ Sağlık Bil Enst Derg. 2012;2(1):24-30.

9. Lusk B, Lash AA. The stress response, psychoneuroimmunology, and stress among ICU patients. Dimens Crit Care Nurs. 2005;24(1):25-31.

10. Meltem U, Korhan EA. Yoğun bakım hastalarında müzik terapinin ağrı ve anksiyete üzerine etkisi. Ağrı. 2011;23(4):139-46.

11. Chalfin DB. Music therapy in critical illness: Entertainment with benefits. Crit Care Med. 2018;46(9):1554-5.

12. Boşnak $M$, Kurt $A H$, Yaman $S$. Beynimizin müzik fizyolojisi. KSÜ Tıp Fak Der. 2017;12(1):35-44.

13. Tanriover G. Müzikle tedavi yöntemleri. Fine Arts. 2010;5(3):150-7.

14. Karamızrak N. Ses ve müziğin organları iyileştirici etkisi. Koşuyolu Kalp Dergisi. 2014;17(1):54-7.

15. Conrad C. Music for healing: From magic to medicine. The Lancet. 2010;376(9757):1980-1.

16. Koç EM, Başer A, Kahveci R, Özkara A. Ruhun ve bedenin gıdası: Geçmişten günümüze müzik ve tıp. Konuralp Tıp Dergisi. 2016;8(1):51-5.

17. Özveren $\mathrm{H}$. Ağrı kontrolünde farmakolojik olmayan yöntemler. HUHEMFAD. 2011;18(1):83-92.

18. Birkan ZI. Müzikle tedavi, tarihi gelişimi ve uygulamaları. Akupunktur Ankara. 2014:37.

19. Sezer E, Atıcı E. Selçuklu ve Osmanlılarda müzikle tedavi yapılan hastaneler. Uludağ Üniversitesi Tıp Fakültesi Dergisi. 2010;36(1):29-32.

20. Loomba RS, Arora R, Shah PH, Chandrasekar S, Molnar J. Effects of music on systolic blood pressure, diastolic blood pressure, and heart rate: A metaanalysis. Indian Heart Journal. 2012;64(3):309-13.
21. Liu Y, Petrini MA. Effects of music therapy on pain, anxiety, and vital signs in patients after thoracic surgery. Complement Ther Med. 2015;23(5):714-8.

22. Kulakaç $N$, Çolak $A$, Aktuğ $C$. Yaşam kalitesi üzerine müziğin etkisi. GÜSBD. 2016;5(4):67-70.

23. T.C. Sağlık Bakanlığı. Geleneksel ve tamamlayıcı tıp uygulamaları yönetmeliği [Internet]. 2014 [Erişim Tarihi 04 Mart 2021]. Erişim adresi: https://www.resmigazete.gov.tr/eskiler/2014/10/2 0141027-3.htm

24. T.C. Cumhurbaşkanlığı Mevzuat Bilgi Sistemi. Hemşirelik yönetmeliği. Çalışılan birim/servis/ünite/alanlara göre hemşirelerin görev, yetki ve sorumlulukları. [Internet]. 2010 [Erişim Tarihi 24 Şubat 2020]. Erişim adresi: https://www.mevzuat.gov.tr/Metin.Aspx?MevzuatK od=7.5.13830\&Mevzuatlliski=0\&sourceXmlSearch=h em\%C5\%9Firelik\%20y.

25. Özden D, Ertuğrul B. Yoğun bakımda hemşirelik hizmetleri. Hancl V, editör. Yoğun Bakımda Organizasyon, Yönetim ve Eğitim. 1. Baskı. Ankara; Türkiye Klinikleri. 2020;1:220-4.

26. Uzelli Yılmaz D, Akın Korhan E, Baysan B, Tan E, Erem $A$, Çelik $S$, ve ark. Mekanik ventilasyon desteğinde olan hastalarda müzik terapinin sedasyon düzeyi ve yaşamsal belirtiler üzerine etkisi: Bir pilot çalışma. iKÇÜSBFD. 2016;1(3):21-7.

27. Alves Al, Rabiais IC, Pestana L, Rodrigues $M$, Ávila $H$, Câmara R, et al. Effects of music therapy in intensive care patients. Int J Nurs. 2016;3(2):88-94.

28. Moher D, Liberati A, Tetzlaff J, Altman DG. Preferred reporting items for systematic reviews and metaanalyses: The PRISMA statement. PLoS Medicine. 2009;6(7):e1000097.

29. Karaçam Z. Sistematik derleme metodolojisi: Sistematik derleme hazırlamak için bir rehber. DEUHYO ED. 2013;6(1):26-33.

30. Çiftçi $H$, Öztunç $G$. The effect of music on comfort, anxiety and pain in the intensive care unit: $A$ case in Turkey. Int J Caring Sci. 2015;8(3):594-602.

31. Aghaie B, Rejeh N, Heravi-Karimooi M, Ebadi A, Moradian ST, Vaismoradi M, et al. Effect of naturebased sound therapy on agitation and anxiety in coronary artery bypass graft patients during the weaning of mechanical ventilation: A randomised clinical trial. Int J Nurs Stud. 2014;51(4):526-38.

32. Hansen IP, Langhorn L, Dreyer P. Effects of music during daytime rest in the intensive care unit. Nurs Crit Care. 2018;23(4):207-13.

33. Lee $C-H$, Lee $C-Y$, Hsu $M-Y$, Lai C-L, Sung $Y-H$, Lin $C-Y$, et al. Effects of music intervention on state anxiety and physiological indices in patients undergoing mechanical ventilation in the intensive care unit: $A$ randomized controlled trial. Biol Res Nurs. 2017;19(2):137-44.

34. Yaman Aktaş $Y$, Karabulut $N$. The effects of music therapy in endotracheal suctioning of mechanically ventilated patients. Nurs Crit Care. 2016;21(1):44-52.

35. Citlik-Saritas S, Saritas S, Cevik-Akyil R, Isik K. The effects of Turkish classical music on physiological 
parameters, pain and analgesic use in patients with myocardial infarction: A non-randomized controlled study. Eur J Integr Med. 2018;22:50-3.

36. Golino AJ, Leone R, Gollenberg A, Christopher C, Stanger D, Davis TM, et al. Impact of an active music therapy intervention on intensive care patients. Am J Crit Care. 2019;28(1):48-55.

37. Liang Z, Ren D, Choi J, Happ MB, Hravnak M, Hoffman LA. Music intervention during daily weaning trials-a 6 day prospective randomized crossover trial. Complementary Therapies in Medicine. 2016;29:727.

38. Ames N, Shuford R, Li Y, Moriyama B, Frey M, Wilson $F$, et al. Music Listening Among Postoperative Patients in the Intensive Care Unit: A Randomized Controlled Trial with Mixed-Methods Analysis. Integr. Med. Insights. 2017(12):1-13.

39. Bayındır S, Koçyiğit F. Yoğun bakım ünitesinde ağrı ve anksiyete yönetiminde nonfarmakolojik adjuvan tedavi: Müzik terapi. Maltepe Tıp Dergisi. 2017;9(1):14-7.

40. Nahcivan N, Seçginli S. Sistematik derlemeye dahil edilen nicel araştırmaların metodolojik kalitesi nasıl değerlendirilir? Turkiye Klinikleri J Public Health Nurs-Special Topics. 2017;3(1):10-9.

41. Messika J, Kalfon P, Ricard J-D. Adjuvant therapies in critical care: Music therapy. Intensive Care Med. 2018;44(11):1929.

42. Sliwka A, Wloch T, Tynor D, Nowobilski R. Do asthmatics benefit from music therapy? A systematic review. Complement Ther Med. 2014;22(4):756-66.

43. Bradt J, Dileo C. Music interventions for mechanically ventilated patients. Cochrane Database of Systematic Reviews. 2014;12. doi: 10.1002/14651858.CD006902.pub3.

44. Mofredj A, Alaya S, Tassaioust K, Bahloul H, Mrabet A. Music therapy, a review of the potential therapeutic benefits for the critically ill. J Crit Care. 2016;35:195-9.

45. Costa F, Ockelford A, Hargreaves DJ. The effect of regular listening to preferred music on pain, depression and anxiety in older care home residents. Psychology of Music. 2018;46(2):174-91.

46. Huang $S-T$, Good $M$, Zauszniewski JA. The effectiveness of music in relieving pain in cancer patients: A randomized controlled trial. Int J Nurs Stud. 2010;47(11):1354-62.

47. Wong $\mathrm{H}$, Lopez-Nahas V, Molassiotis A. Effects of music therapy on anxiety in ventilator-dependent patients. Heart Lung. 2001;30(5):376-87.

48. Chlan LL, Weinert CR, Heiderscheit A, Tracy MF, Skaar DJ, Guttormson JL, et al. Effects of patient-directed music intervention on anxiety and sedative exposure in critically ill patients receiving mechanical ventilatory support: A randomized clinical trial. Jama. 2013;309(22):2335-44.

49. Altan Sarıkaya N, Oğuz S. Huzurevinde kalan yaşlılarda pasif müzikoterapinin uyku kalitesine etkisi. Psikiyatri Hemşireliği Dergisi. 2016;7(2):55-60.
50. Nilsson $U$. The effect of music intervention in stress response to cardiac surgery in a randomized clinical trial. Heart Lung. 2009;38(3):201-7. 